\title{
Pratylenchus penetrans population dynamics and cabbage growth under the continuous application of sawdust cattle manure compost for year-round cabbage cropping ${ }^{1}$
}

\begin{abstract}
A tsuko Uragami ${ }^{2,}{ }^{*}$, Sin-ichi Tokuda22, Fumio Sato2, M iyuki K unihisa ${ }^{2,3}$, Kenji M urakami ${ }^{2,4}$, Hisao Higashio2, ${ }^{2}$, Shoko A izawa ${ }^{2}$ and K unihiko Okada²

Pratylenchus penetrans is a major nematode pest of vegetable crops in Japan. We investigated $P$. penetrans population dynamics and cabbage growth under the year-round application of sawdust cattle manure compost for continuous cabbage cropping (2002-2009) at Tsukuba, Japan. Cabbages were cultivated twice a year, during spring and autumn. Chemical fertilizer (CF), manure compost (MC) $+1 / 5 C F, C F+$ $3 / 5 M C+$ crop residue $(C R)$, a triple amount of $M C+1 / 5 C F$, and $3 M C+C R$ were applied to the field before transplanting the cabbages. Both the initial population $(\mathrm{Pi})$ and final population $(\mathrm{Pf})$ of $\mathrm{P}$. penetrans were significantly high in $C F$, low in $3 M C+1 / 5 C F$ and $3 M C+C R$, and average in $M C+1 / 5 C F$ and $C F+3 / 5 M C+$ CR in 2003-2005 and 2008-2009. B oth Pf/Pi during cultivation and the decreased rate of Pi/P f after cultivation showed no clear tendencies among compost treatments. In this study, host plant grow th did not appear to be markedly restricted by the high densities of P. penetrans. By applying Seinhorst's formula on the Pi and Pf of $P$. penetrans, we obtained 2 curves for $C F$ and $3 M C+C R$, with 16.45 and 4.54 representing "equilibrium density", respectively. Pot experiment results supported the field experiment results, whereby the number of $P$. penetrans decreased as the quantity of MC increased (from 0 to $3 \% \mathrm{w} / \mathrm{v}$ ). On the basis of these results, we concluded that manure compost application could have a suppressive effect on P. penetrans population dynamics. Nematol. Res. 45(1), 1-11 (2015).
\end{abstract}

K ey words: Brassica oleracea L. var. capitata L., root lesion nematode, amendment, continuous cropping

\section{INTRODUCTION}

Pratylenchus penetrans Cobb is one of the most important plant-parasitic nematodes in Japan and causes severe damage to vegetables, which reduces crop quality and hence marketability. Vegetable crops affected by this nematode include the Japanese radish (Raphanus sativus L. var. longipinnatus) (Chikaoka et al., 1971), carrot (D aucus carota L.) (Hagiya et al., 1982), and edible burdock (Arctium lappa L.) (K ajino, 1986). Organic soil supplements have long been utilized to control nematode damage (Nakasono, 1992). As a result, many studies have

\footnotetext{
${ }^{1}$ Parts of this article were presented at the 16th and 17th annual meetings of the Japanese Nematological Society.

${ }^{2} \mathrm{~N}$ ational A griculture and Food Research Organization (NARO) Institute of Vegetable and Tea Science, K annon-dai 3-1-1, Tsukuba, I baraki 305-8666, Japan.

${ }^{3}$ Present address: National Institute of Fruit Tree Science, 2-1 Fujimoto, Tsukuba, Ibaraki 305-8605, Japan.

${ }^{4}$ Present address: NA RO Western Region A gricultural Research Center, 200 U eno, Uenocho, Ayabe, Kyoto 623-0035, Japan.

${ }_{5}^{5}$ Present address: I baraki University, 3-21-1, Chuuo, A mi, Inashiki, I baraki 300-0393, Japan.

*Corresponding author, e-mail: atsuko@ affrc.go.jp
}

focused on evaluating how organic soil supplements suppress the effects of parasitic nematodes, including $P$. penetrans (Nakasono, 1992; Ohbayashi, 1989; Oka, 2010; U ragami et al., 2009). A lthough compost application has had variable effects on the populations of plant-parasitic nematodes, the population dynamics of $P$. penetrans under compost application remain unresolved (Nakasono, 1992; Oka, 2010).

In 2002, a continuous compost application experiment was initiated in a cabbage (Brassica oleracea L. var. capitata L.) field at Tsukuba Vegetable Research Station, National A griculture and Food Research Organization (NARO) Institute of Vegetable and Tea Science, Japan. Cabbage is known to be a good host of $P$. penetrans, with high nematode population densities only minimally reducing cabbage grow th (M iller, 1978; Olthof and Potter, 1973). In this study, we aimed to characterize the population dynamics of $P$. penetrans under continuous cabbage cropping conditions with the continuous application of different volumes of sawdust cattle manure compost. 


\section{MATERIALS AND METHODS}

Field experiments:

Field experiments were conducted in an experimental field located at the NARO Institute of Livestock and Grassland Science, Tsukuba, Japan $\left(36^{\circ} 02^{\prime} \mathrm{N}, 140^{\circ} 11^{\prime} \mathrm{E}\right.$; $21 \mathrm{~m}$ above sea level). The soil type is A ndosol, containing $49 \%$ sand, $46 \%$ silt, and $5 \%$ clay. Soil pH and electrical conductivity (EC) immediately prior to the experiment were 7 and $17.5 \mathrm{mS} / \mathrm{m}$, respectively. This experimental field was naturally infested with $P$. penetrans before cabbage cultivation. $P$. penetrans was identified on the basis of morphological characteristics (M izukubo, 2004).

In September 2002, a compost application experiment comprising 5 treatments (Table 1) was established in a randomized complete block design with 3 replications. Individual plots of $5 \times 5 \mathrm{~m}$ were delineated, each with lanes of $2 \mathrm{~m}$ in width. B efore 2002, rye (Secale cereale L.) or dent corn (Zea mays L. var. indentata) had been cultivated in the field for approximately 15 years, with $117 \mathrm{~kg} / \mathrm{ha}$ nitrogen $(\mathrm{N})$ of chemical fertilizer and 21 tha of compost being applied each year.

The basic amount of applied commercial sawdust cattle manure compost (MC) included approximately 250 $\mathrm{kg} / \mathrm{ha} \mathrm{N}$, based on component analysis results (Table 2). Sawdust cattle manure compost was incorporated twice a year to $15-\mathrm{cm}$ depth by using a rotary tiller, approximately 1 month before the cabbages were transplanted. Chemical fertilizer (CF; K asei No. 8, Ryoto Hiryo Co. Ltd, Japan; $\mathrm{N}$ : 8; $\mathrm{P}_{2} \mathrm{O}_{5}: 8 ; \mathrm{K}_{2} \mathrm{O}: 8$ ) was applied immediately before transplanting each cabbage crop. Crop residue (CR, i.e., outer leaves and roots) was incorporated into the field after harvesting the cabbage heads. In all other treatments, crop residue was removed from the field. Cabbage seedlings (cultivar "K inkei 201" for spring cultivation and "Shutoku" or "Shutoku SP" for autumn cultivation) were transplanted to the experimental field twice a year (spring and autumn), with continuous cultivation from September 2002 to September 2009. For the spring cultivation, cabbage seedlings were transplanted at the beginning of A pril and harvested in approximately late June. For the autumn cultivation, cabbages were transplanted at the beginning of September and harvested in the middle of December. A fter transplanting, cabbages were irrigated once by hand with a hose to ensure they survived. Cabbages were spaced at $0.4-\mathrm{m}$ intervals within rows and at $0.6-\mathrm{m}$ intervals between rows ( 7 rows per plot) with 77 plants per plot. During each cultivation period, no supplemental fertilization was applied. Pesticides, fungicides, and herbicides were applied when needed; however, chemical soil disinfectants were not applied.

\section{Data collection:}

The total carbon and nitrogen contents of the soils, which were collected just after every cabbage cultivation, were estimated using a nitrogen and carbon analyzer (Sumigraph NC-22F; Sumika Chemical A nalysis Service Ltd., Tokyo, Japan). Soil pH and EC were also analyzed using a pH meter (F-14; HORIBA, Kyoto, Japan).

At harvest, 4 uniformly grown healthy cabbage plants were cut from the ground of each plot and individually weighed, with the average of the 4 plants being used for data analysis.

From M ay 2003 to J une 2005 and from September 2008 to December 2009, the population levels of $P$. penetrans and free-living nematodes in the soil were assessed immediately before transplanting the cabbages

Table 2. Compositions of the compost used in the experiment

\begin{tabular}{ccccc}
\hline Y ear & $\mathrm{N}(\%)$ & $\mathrm{P}_{2} \mathrm{O}_{5}(\%)$ & $\mathrm{K}_{2} \mathrm{O}(\%)$ & $\begin{array}{r}\mathrm{C} / \mathrm{N} \\
\text { ratio }\end{array}$ \\
\hline 2003 & 2.5 & - & - & 17 \\
2006 & 2.4 & 2.1 & 2.7 & 16.6 \\
2009 & 3.7 & 2.3 & 3.5 & 11 \\
\hline
\end{tabular}

The commercial manure compost was analyzed before each application

Table 1. A mount of organic materials and nitrogen incorporated into the plot per cabbage planting for 5 different treatments

\begin{tabular}{lccc}
\hline \multicolumn{1}{c}{ Treatment } & $\begin{array}{c}\text { Treatment } \\
\text { abbreviation }\end{array}$ & $\begin{array}{c}\text { Organic } \\
\text { material } \\
\text { (tFW } / \text { ha) }\end{array}$ & $\begin{array}{c}\text { Nitrogen } \\
(\mathrm{kg} / \mathrm{ha})\end{array}$ \\
\hline Chemical fertilizer & $\mathrm{CF}$ & 0 & 250 \\
M anure compost $+1 / 5$ of chemical fertilizer & $\mathrm{M} \mathrm{C}+1 / 5 \mathrm{CF}$ & 32 & $250+50$ \\
Chemical fertilizer $+3 / 5$ of manure compost + crop residue & $\mathrm{CF}+3 / 5 \mathrm{M} \mathrm{C}+\mathrm{CR}$ & $20+33$ & $250+150+80$ \\
Triple amount of manure compost $+1 / 5$ of chemical fertilizer & $3 \mathrm{M} \mathrm{C}+1 / 5 \mathrm{CF}$ & 97 & $750+50$ \\
Triple amount of manure compost + crop residue & $3 \mathrm{M} \mathrm{C} \mathrm{+} \mathrm{CR}$ & $97+33$ & $750+80$ \\
\hline
\end{tabular}


(Pi: initial population) and just after harvest (Pf: final population). The first 3 years and the last 2 years in the 7 years of cabbage cultivation with compost treatment were assessed for nematode densities. For $M C+1 / 5 C F$ and $3 \mathrm{MC}+1 / 5 \mathrm{CF}$, the assessment began from July 2003 , i.e., Pf in spring 2003 (2003S). In 2009, the nematode population assessments were also performed on January 19, February 19, M arch 19, A ugust 14, and October 21. The population assessment for each plot in each sampling period was based on a composite sample of 9 soil subsamples collected from a depth of $5-15 \mathrm{~cm}$, totaling approximately $1 \mathrm{~kg}$ wet weight. Soil samples were passed through a sieve with 2-mm openings to remove the cabbage roots and were gently hand-mixed. Nematodes were extracted from two 20-g subsamples, using the Baermann funnel method, for $72 \mathrm{hr}$ at room temperature. The number of nematodes was counted using a biological microscope (E-600; Nikon, Tokyo, Japan), and was calculated as the average of the 2 subsamples. Seasonal multiplication rates were calculated as the $\mathrm{Pf} / \mathrm{Pi}$ of a cultivation period, and the rates of decline during fallow periods were calculated as $\mathrm{Pi} / \mathrm{Pf}$ by using the $\mathrm{Pf}$ of a cultivation period and the $\mathrm{Pi}$ of the following period.

Data for hourly soil temperatures at $10-\mathrm{cm}$ depth were obtained from the website for the National Institute for A gro-Environmental Sciences. These measurements were made using a New A utomated Weather System located approximately $1 \mathrm{~km}$ northwest of the experimental field $\left(36^{\circ} 01^{\prime} \mathrm{N}, 140^{\circ} 07^{\prime} \mathrm{E} ; 25 \mathrm{~m}\right.$ above sea level). The effective accumulative temperatures (degreedays) for $P$. penetrans development during each cultivation period were calculated using developmental zero degree of $4.2^{\circ} \mathrm{C}$ (M izukubo and A dachi, 1997).

\section{Pot experiments:}

Soil was collected from CF plots just after the cabbage harvest on July 20,2010, and passed through a 2-mm sieve. Eleven kilograms of the soil was then placed into a 15-I plastic pot (surface area, $500 \mathrm{~cm}^{2}$; height, 30 $\mathrm{cm})$. Zero percent, $1 \%$, and $3 \%(\mathrm{w} / \mathrm{v})(0,30$, and $90 \mathrm{t} / \mathrm{ha}$, respectively) of commercial sawdust cattle manure compost used in the field experiment was incorporated into the pot. The average soil moisture content was 0.52 $(\mathrm{g} / \mathrm{g})$. Each treatment contained 10 pots, which were maintained in a glass house. Average, maximum, and minimum soil temperatures at $5-\mathrm{cm}$ depth during the experiment were 28,38 , and $24^{\circ} \mathrm{C}$, respectively. The water content of the pots was kept uniform by weighing and refilling the pots with water to the original weight once a week. Nematodes were extracted at 45 and 76 days after treatment. The population assessment for each pot was based on two 20-g soil samples. Nematodes were extracted from each sample by using the Baermann funnel method, with counts following the same technique as that used for the field experiments.

Statistical analysis and model formula analysis:

Statistical analysis was performed using Statistica 6.0 (Statsoft J apan). We conducted analysis of variance (A NOVA) and Tukey's HSD test on cabbage weight; soil properties; $\mathrm{Pi}, \mathrm{Pf}, \mathrm{Pi} / \mathrm{Pf}$, and $\mathrm{Pf} / \mathrm{Pi}$; and nematode populations in pots. $\mathrm{Pi}, \mathrm{Pf}, \mathrm{Pi} / \mathrm{Pf}, \mathrm{Pf} / \mathrm{Pi}$ and nematode populations in pots were analyzed after Box-Cox transformation because of the lack of normality and homoscedasticity.

The model used to assess the relationship between initial and final nematode densities, developed by Seinhorst (1966) for migratory nematodes (such as P ratylenchus spp.), is as follows:

$$
P f=\frac{a E P i}{(a-1) P i+E}
$$

where $\mathrm{a}=$ rate of multiplication at $\mathrm{Pi} \rightarrow 0$ and $\mathrm{E}=$ equilibrium density

We applied this model to the regression analysis of $P$. penetrans population data from the field experiments, to quantify how compost application inhibited an increase in nematode population size (24 sets of $\mathrm{Pi}$ and $\mathrm{Pf}$ for $\mathrm{CF}$ and $C F+3 / 5 M C+C R, 21$ sets for $M C+1 / 5 C F$ and $3 M C$ $+C R$, and 18 sets for $3 M C+1 / 5 C F$, respectively). Three samples of $3 M C+C R$ with $P f / P i$ values below 1 were removed as aberrant values. M odel formula analysis was performed with $\mathrm{DataFit} 9$ software (Oakdale Engineering, Oakdale, U.S.A.).

\section{RESULTS}

Cabbage grow th and soil properties:

Until the 2004 spring cropping season, cabbage growth (based on the weight of the above-ground part of the plant) was greater in $\mathrm{CF}$ and $\mathrm{CF}+3 / 5 \mathrm{MC}+\mathrm{CR}$ than in $M C+1 / 5 C F, 3 M C+1 / 5 C F$, and $3 M C+C R$ (Table 3 ). A fter the 2004 autumn cropping season, the growth of cabbages in plots with $3 \mathrm{MC}$ was similar to that of cabbages in plots with CF. Cabbage growth in the CF + $3 / 5 \mathrm{M} \mathrm{C}+\mathrm{CR}$ plots remained consistently high until the end of the experiments in 2009. A ccording to the factorial analysis on the cabbage above-ground weights, there were no significant differences between the spring and autumn plantings in 2003 and $2004(P=0.765)$ and in 2009 (0.054), respectively.

Total nitrogen and total carbon content of the soil for 
all treatments, except $C F$, increased with time. This increase was noticeably rapid for $3 \mathrm{MC}+1 / 5 \mathrm{CF}$ and $3 \mathrm{MC}$ $+\mathrm{CR}$ (Table 4). The soil pH of CF, CF + 3/5MC + CR, and $M C+1 / 5 C F$ decreased with time, whereas that for the other compost types changed minimally. The soil EC of $C F+3 / 5 M C+C R$ remained consistently high for all other plots.

\section{Nematode population:}

The number of $P$. penetrans on $M$ ay 23,2003 , in uncultivated areas adjacent to the experimental plot was $2.80 \pm 0.73 / \mathrm{g}$ soil $(n=3)$.
When we performed A NOVA on Pi and Pf of P. penetrans in two parts (2003-2005 and 2008-2009), there were significant differences among treatments $(P<0.001$ for all ANOVA). B oth $\mathrm{Pi}$ and $\mathrm{Pf}$ of $\mathrm{P}$. penetrans were high in $C F$ and low in $3 M C+1 / 5 C F$ and $3 M C+C R$ in 2003-2005 and 2008-2009 (Table 5). Pi of P. penetrans in CF plots showed the highest mean value among all treatments, except in autumn 2009 (2009A) (Table 5). Pi of $P$. penetrans in $3 M C+1 / 5 C F$ and $3 M C+C R$ showed the lowest mean values among all treatments. The ranges of $\mathrm{Pi}$ for $\mathrm{CF}, \mathrm{CF}+3 / 5 \mathrm{MC}+\mathrm{CR}, \mathrm{MC}+1 / 5 \mathrm{CF}, 3 \mathrm{MC}+$ $1 / 5 C F$, and $3 M C+C R$ were $1.77-9.32,0.46-3.80,1.25-$

Table 3. A bove-ground weight $(\mathrm{kg})$ of cabbage plants (i.e, excluding the roots) in spring (S) and autumn (A) cabbage cultivation during the 5 trial years in a Pratylenchus penetrans-infested field

\begin{tabular}{lllllllll}
\hline \multicolumn{1}{c}{ Treatment } & $2003 \mathrm{~S}$ & $2003 \mathrm{~A}$ & $2004 \mathrm{~S}$ & $2004 \mathrm{~A}$ & $2005 \mathrm{~S}$ & $2008 \mathrm{~A}$ & $2009 \mathrm{~S}$ & $2009 \mathrm{~A}$ \\
\hline $\mathrm{CF}$ & $2.63 \mathrm{a}$ & $2.26 \mathrm{ab}$ & $2.73 \mathrm{a}$ & $1.93 \mathrm{ab}$ & $2.75 \mathrm{ab}$ & $2.24 \mathrm{ab}$ & $2.88 \mathrm{ab}$ & $2.63 \mathrm{~b}$ \\
$\mathrm{MC}+1 / 5 \mathrm{CF}$ & $1.91 \mathrm{~b}$ & $1.55 \mathrm{c}$ & $1.34 \mathrm{~b}$ & $1.69 \mathrm{~b}$ & $1.82 \mathrm{c}$ & $1.53 \mathrm{c}$ & $2.33 \mathrm{~b}$ & $2.00 \mathrm{c}$ \\
$\mathrm{CF}+3 / 5 \mathrm{MC}+\mathrm{CR}$ & $2.61 \mathrm{a}$ & $2.33 \mathrm{ab}$ & $2.87 \mathrm{a}$ & $1.97 \mathrm{ab}$ & $3.19 \mathrm{a}$ & $2.54 \mathrm{a}$ & $3.27 \mathrm{a}$ & $3.09 \mathrm{a}$ \\
$3 \mathrm{MC}+1 / 5 \mathrm{CF}$ & $1.94 \mathrm{~b}$ & $2.02 \mathrm{~b}$ & $1.48 \mathrm{~b}$ & $2.11 \mathrm{a}$ & $2.47 \mathrm{bc}$ & $2.05 \mathrm{ab}$ & $2.97 \mathrm{ab}$ & $2.97 \mathrm{ab}$ \\
$3 \mathrm{MC}+\mathrm{CR}$ & $1.34 \mathrm{c}$ & $1.63 \mathrm{c}$ & $0.84 \mathrm{~b}$ & $1.91 \mathrm{ab}$ & $2.50 \mathrm{bc}$ & $1.86 \mathrm{bc}$ & $2.73 \mathrm{ab}$ & $2.69 \mathrm{~b}$ \\
\hline
\end{tabular}

Values represent the means of 3 replicates.

$M$ eans followed by the same letter in each column were not significantly different according to Tukey's HSD test at the $5 \%$ level.

Chemical fertilizer (CF), manure compost (MC), and crop residue (CR), either separately or in combination, were applied before transplanting the cabbages.

Table 4. Soil properties of the experimental plots during continuous cabbage cultivation in plots treated with organic materials

\begin{tabular}{|c|c|c|c|c|c|}
\hline Date & Treatment & $\begin{array}{c}\text { Total-N } \\
(\mathrm{g} / \mathrm{kg})\end{array}$ & $\begin{array}{c}\text { Total-C } \\
(\mathrm{g} / \mathrm{kg})\end{array}$ & $\mathrm{pH}$ & $\begin{array}{c}\mathrm{EC} \\
(\mathrm{mS} / \mathrm{m})\end{array}$ \\
\hline \multirow{5}{*}{$2003 / 8 / 12$} & $\mathrm{CF}$ & $3.2 \mathrm{a}$ & $35.1 \mathrm{a}$ & $6.5 \mathrm{~d}$ & 25 cdef \\
\hline & $M C+1 / 5 C F$ & $3.7 \mathrm{abcd}$ & $40.2 \mathrm{abc}$ & $7.2 \mathrm{gh}$ & $16 \mathrm{ab}$ \\
\hline & $C F+3 / 5 M C+C R$ & $3.6 a b c$ & $38.0 \mathrm{ab}$ & $6.8 \mathrm{e}$ & $34 \mathrm{gh}$ \\
\hline & $3 \mathrm{MC}+1 / 5 \mathrm{CF}$ & 4.5 def & 50.6 ef & $7.2 \mathrm{gh}$ & 22 bcdef \\
\hline & $3 M C+C R$ & 5.0 ef & $53.9 \mathrm{f}$ & $7.2 \mathrm{gh}$ & $28 \mathrm{fgh}$ \\
\hline \multirow{5}{*}{$2006 / 7 / 24$} & $\mathrm{CF}$ & $3.3 \mathrm{ab}$ & $35.6 \mathrm{a}$ & $5.3 \mathrm{~b}$ & $19 \mathrm{abcde}$ \\
\hline & $M C+1 / 5 C F$ & 4.1 bcde & $42.8 \mathrm{bcd}$ & 6.9 ef & 13 a \\
\hline & $C F+3 / 5 M C+C R$ & 4.4 cdef & 45.6 cde & $6.1 \mathrm{c}$ & 25 def \\
\hline & $3 \mathrm{MC}+1 / 5 \mathrm{CF}$ & $6.4 \mathrm{~g}$ & $66.5 \mathrm{~g}$ & $7.2 \mathrm{gh}$ & $17 \mathrm{abc}$ \\
\hline & $3 M C+C R$ & $6.3 \mathrm{~g}$ & $65.0 \mathrm{~g}$ & $7.4 \mathrm{~h}$ & $18 \mathrm{abcd}$ \\
\hline \multirow{5}{*}{$2009 / 7 / 28$} & $\mathrm{CF}$ & $3.4 a b$ & $36.2 \mathrm{ab}$ & $4.6 \mathrm{a}$ & 26 efg \\
\hline & $M C+1 / 5 C F$ & $5.2 f$ & 50.4 ef & $6.7 \mathrm{de}$ & $14 a b$ \\
\hline & $C F+3 / 5 M C+C R$ & 4.9 ef & 48.2 def & $5.2 \mathrm{~b}$ & $45 \mathrm{i}$ \\
\hline & $3 M C+1 / 5 C F$ & $8.8 \mathrm{~h}$ & $77.6 \mathrm{~h}$ & $7.1 \mathrm{fg}$ & 20 abcde \\
\hline & $3 M C+C R$ & $9.1 \mathrm{~h}$ & $86.0 \mathrm{i}$ & $7.1 \mathrm{fgh}$ & $35 \mathrm{~h}$ \\
\hline
\end{tabular}

Values represent the means of 3 replicates.

$\mathrm{M}$ eans followed by the same letter in each column were not significantly different according to Tukey's HSD test at the $5 \%$ level.

Chemical fertilizer (CF), manure compost (MC), and crop residue (CR), either separately or in combination, were applied before transplanting the cabbages. 
Table 5. The initial population ( $\mathrm{Pi})$, the final population (Pf), and the multiplication rate (Pf/Pi) of Pratylenchus penetrans in plots treated with organic materials during spring (S) and autumn (A) cabbage cultivation in each year

\begin{tabular}{|c|c|c|c|c|c|c|c|c|c|}
\hline & \multicolumn{3}{|c|}{$2003 \mathrm{~S}$} & \multicolumn{3}{|c|}{$2003 \mathrm{~A}$} & \multicolumn{3}{|c|}{$2004 S$} \\
\hline & $\mathrm{Pi}^{1}$ & $\mathrm{Pf}^{1}$ & $\mathrm{Pf} / \mathrm{Pi}$ & $\mathrm{Pi}$ & Pf & $\mathrm{Pf} / \mathrm{Pi}$ & $\mathrm{Pi}$ & Pf & $\mathrm{Pf} / \mathrm{Pi}$ \\
\hline CF & $6.68 \mathrm{a}$ & $11.08 \mathrm{a}$ & $2.02 \mathrm{a}$ & $3.20 \mathrm{a}$ & $10.11 \mathrm{a}$ & $3.08 \mathrm{a}$ & $4.47 \mathrm{a}$ & $28.24 \mathrm{a}$ & $7.50 \mathrm{ab}$ \\
\hline$M C+1 / 5 C F$ & - & $4.63 a b$ & - & $2.10 a b$ & $5.26 \mathrm{ab}$ & $2.65 \mathrm{a}$ & $3.47 \mathrm{a}$ & $11.98 \mathrm{~b}$ & $6.50 \mathrm{ab}$ \\
\hline$C F+3 / 5 M C+C R$ & $3.18 \mathrm{ab}$ & $1.69 \mathrm{bc}$ & $0.79 a$ & $0.73 b c$ & $2.81 \mathrm{ab}$ & $4.69 \mathrm{a}$ & $0.68 \mathrm{a}$ & $7.0 \mathrm{~b}$ & $12.98 \mathrm{a}$ \\
\hline $3 \mathrm{MC}+1 / 5 \mathrm{CF}$ & - & $1.05 \mathrm{C}$ & - & $0.39 \mathrm{c}$ & $3.40 \mathrm{ab}$ & $7.97 \mathrm{a}$ & $1.10 \mathrm{a}$ & $2.40 \mathrm{C}$ & $2.54 \mathrm{ab}$ \\
\hline $3 M C+C R$ & $0.21 \mathrm{~b}$ & $0.93 \mathrm{C}$ & $6.26 \mathrm{a}$ & $0.52 \mathrm{c}$ & $1.81 \mathrm{~b}$ & $3.75 \mathrm{a}$ & $2.11 \mathrm{a}$ & $1.08 \mathrm{C}$ & $0.58 \mathrm{~b}$ \\
\hline
\end{tabular}

\begin{tabular}{lccccccc}
\hline & \multicolumn{3}{c}{$2004 \mathrm{~A}$} & & \multicolumn{3}{c}{$2005 \mathrm{~S}$} \\
\cline { 2 - 4 } \cline { 6 - 8 } & $\mathrm{Pi}$ & $\mathrm{Pf}$ & $\mathrm{Pf} / \mathrm{Pi}$ & & $\mathrm{Pi}$ & $\mathrm{Pf}$ & $\mathrm{Pf} / \mathrm{Pi}$ \\
\hline $\mathrm{CF}$ & $1.77 \mathrm{a}$ & $12.16 \mathrm{a}$ & $6.96 \mathrm{a}$ & & $9.32 \mathrm{a}$ & $18.24 \mathrm{a}$ & $2.01 \mathrm{a}$ \\
$\mathrm{MC}+1 / 5 \mathrm{CF}$ & $1.25 \mathrm{ab}$ & $9.98 \mathrm{a}$ & $8.62 \mathrm{a}$ & & $3.55 \mathrm{~b}$ & $8.34 \mathrm{ab}$ & $2.34 \mathrm{a}$ \\
$\mathrm{CF}+3 / 5 \mathrm{M} C+\mathrm{CR}$ & $0.46 \mathrm{ab}$ & $3.73 \mathrm{~b}$ & $10.37 \mathrm{a}$ & & $2.63 \mathrm{~b}$ & $13.58 \mathrm{a}$ & $5.05 \mathrm{a}$ \\
$3 \mathrm{MC}+1 / 5 \mathrm{CF}$ & $0.52 \mathrm{ab}$ & $2.14 \mathrm{~b}$ & $6.93 \mathrm{a}$ & & $1.53 \mathrm{c}$ & $2.23 \mathrm{bc}$ & $1.40 \mathrm{a}$ \\
$3 \mathrm{MC}+\mathrm{CR}$ & $0.14 \mathrm{~b}$ & $0.48 \mathrm{c}$ & $8.10 \mathrm{a}$ & & $1.00 \mathrm{c}$ & $1.32 \mathrm{c}$ & $1.35 \mathrm{a}$ \\
\hline
\end{tabular}

\begin{tabular}{|c|c|c|c|c|c|c|c|c|c|}
\hline & \multicolumn{3}{|c|}{$2008 \mathrm{~A}$} & \multicolumn{3}{|c|}{20095} & \multicolumn{3}{|c|}{$2009 A$} \\
\hline & $\mathrm{Pi}$ & $\mathrm{Pf}$ & $\mathrm{Pf} / \mathrm{Pi}$ & $\mathrm{Pi}$ & Pf & $\mathrm{Pf} / \mathrm{Pi}$ & $\mathrm{Pi}$ & Pf & $\mathrm{Pf} / \mathrm{Pi}$ \\
\hline $\mathrm{CF}$ & $3.74 \mathrm{a}$ & $7.89 a$ & $2.15 \mathrm{a}$ & $7.12 \mathrm{a}$ & $15.77 \mathrm{a}$ & $2.44 \mathrm{a}$ & $2.28 \mathrm{ab}$ & $4.89 \mathrm{a}$ & $2.15 \mathrm{~b}$ \\
\hline$M C+1 / 5 C F$ & $1.63 \mathrm{bc}$ & $4.28 \mathrm{ab}$ & $2.57 \mathrm{a}$ & $4.26 \mathrm{a}$ & $7.88 \mathrm{ab}$ & $1.66 \mathrm{a}$ & $3.38 \mathrm{a}$ & $6.49 \mathrm{a}$ & $1.35 \mathrm{~b}$ \\
\hline$C F+3 / 5 M C+C R$ & $2.37 \mathrm{ab}$ & $4.23 \mathrm{ab}$ & $1.85 \mathrm{a}$ & $3.80 \mathrm{a}$ & $12.69 \mathrm{a}$ & $3.58 \mathrm{a}$ & $0.89 \mathrm{~b}$ & $4.67 \mathrm{a}$ & $7.44 \mathrm{a}$ \\
\hline $3 \mathrm{MC}+1 / 5 \mathrm{CF}$ & $0.75 c$ & $1.81 b c$ & $2.65 \mathrm{a}$ & $1.98 \mathrm{a}$ & $3.81 \mathrm{~b}$ & $1.96 \mathrm{a}$ & $0.82 \mathrm{~b}$ & $2.08 \mathrm{~b}$ & $2.82 \mathrm{~b}$ \\
\hline $3 M C+C R$ & $0.53 c$ & $1.60 \mathrm{C}$ & $3.35 \mathrm{a}$ & $2.48 \mathrm{a}$ & $3.48 b$ & $1.56 \mathrm{a}$ & $0.77 \mathrm{~b}$ & $2.33 \mathrm{~b}$ & $3.33 \mathrm{~b}$ \\
\hline
\end{tabular}

${ }^{1} \mathrm{Pi}=$ initial population and $\mathrm{Pf}=$ final population of $\mathrm{P}$. penetrans in each cultivation period per $\mathrm{g}$ soil extracted from $20 \mathrm{~g}$ soil (Baermann funnel method).

Cabbage plants were cultivated twice a year in spring and autumn.

$\checkmark$ alues represent the means of 3 replicates.

$\mathrm{Pi}, \mathrm{Pf}$ and $\mathrm{Pf} / \mathrm{Pi}$ were analyzed after $\mathrm{B}$ ox-C ox transformation to reduce non-normality.

Means followed by the same letter in each colomn were not significantly different according to Tukey's HSD test at the $5 \%$ level.

Chemical fertilizer (CF), manure compost (MC), and crop residue (CR), either separately or in combination, were applied before transplanting the cabbages.

4.26, 0.39-1.98, and 0.14-2.48, respectively. All the mean values of $P f / P i$, except $C F+3 / 5 M C+C R$ in $2003 S$ and $3 M C+C R$ in 2004S, were $>1$, showing that the $P$. penetrans population increased during cabbage cultivation. $\mathrm{Pf} / \mathrm{Pi}$ during the 8 cultivation seasons ranged from 0.58 to 12.98 , with no statistical trend among treatments (A N OVA, P > 0.05, df: 4, M S: 0.709, F-value: 1.088).

Comparison of the mean $\mathrm{Pf}$ values among treatments showed that the $P f$ values of $C F$ remained the highest until the spring cultivation in 2009 (Table 5). The ranges of $\mathrm{Pf}$ for $\mathrm{CF}, \mathrm{MC}+1 / 5 \mathrm{CF}, \mathrm{CF}+3 / 5 \mathrm{MC}+\mathrm{CR}, 3 \mathrm{MC}+$ $1 / 5 \mathrm{CF}$, and $3 \mathrm{MC}+\mathrm{CR}$ were $4.89-28.24,4.28-11.98,1.69-$ $13.58,1.05-3.81$, and $0.48-3.48$, respectively. All mean $\mathrm{Pi} /$ Pf values, except $3 M C+C R$ in $2003 A$ and $M C+1 / 5 C F$ in $2008 \mathrm{~A}$, were $<1$, indicating that the $P$. penetrans population size decreased af ter cabbage cultivation (Table 6). Pi/Pf ranged from 0.07 to 1.59 , with no statistical trend among treatments (A NOVA , P >0.05, df:
4, M S: 0.760, F -value: 2.082).

The populations of $P$. penetrans increased during cabbage cultivation and decreased after the harvest, as $95 \%$ of the $\mathrm{Pf} / \mathrm{Pi}$ values were more than 1 and $90 \%$ of the $\mathrm{Pi} / \mathrm{Pf}$ values were less than 1 (Table 5 ). These tendencies were not clear in free-living nematodes, especially during autumn cultivation when $60 \%$ of the $\mathrm{P} / \mathrm{Pi}$ values of 20 treatments were less than 1 (Table 7).

We also performed A NOVA on the P $i$ and P $f$ of freeliving nematodes (i.e., nematodes other than plantfeeding species) in two parts (2003-2005 and 2008-2009) and found that there were clear differences among treatments ( $P<0.001$ for all A NOVA, data not shown). $B$ oth the $\mathrm{Pi}$ and $\mathrm{Pf}$ of free-living nematodes were high in $3 M C+1 / 5 C F$ and $3 M C+C R$ and low in CF in 20032005 and in 2008-2009 (Table 7). In CF + 3/5M C + CR and $M C+1 / 5 C F$, the mean $P i$ and $P f$ values were higher than those of CF. The mean Pi and Pf values of freeliving nematodes in the treatments tended to reflect the 
Table 6. The rate of population decline (Pi/Pf) of Pratylenchus penetrans in plots treated with organic materials after spring (S) and autumn (A) cabbage cultivation in each year.

\begin{tabular}{|c|c|c|c|c|}
\hline Treatment & $2003 S$ & $2003 \mathrm{~A}$ & $2004 S$ & $2004 \mathrm{~A}$ \\
\hline$\overline{C F}$ & $0.30 \mathrm{a}$ & $0.51 \mathrm{ab}$ & $0.63 a$ & $0.83 \mathrm{ab}$ \\
\hline$M C+1 / 5 C F$ & $0.45 \mathrm{a}$ & $0.68 \mathrm{ab}$ & $0.12 \mathrm{a}$ & $0.37 \mathrm{~b}$ \\
\hline$C F+3 / 5 M C+C R$ & $0.47 \mathrm{a}$ & $0.23 \mathrm{~b}$ & $0.61 \mathrm{a}$ & $0.29 \mathrm{~b}$ \\
\hline $3 \mathrm{MC}+1 / 5 \mathrm{CF}$ & $0.56 a$ & $0.43 a b$ & $0.24 \mathrm{a}$ & $0.80 a b$ \\
\hline $3 M C+C R$ & $0.67 \mathrm{a}$ & $1.59 \mathrm{a}$ & $0.13 \mathrm{a}$ & $2.47 \mathrm{a}$ \\
\hline Treatment & $2008 \mathrm{~A}$ & $2009 S$ & & \\
\hline$C F$ & $0.85 a$ & $0.15 b c$ & & \\
\hline$M C+1 / 5 C F$ & $1.22 \mathrm{a}$ & $0.52 \mathrm{a}$ & & \\
\hline$C F+3 / 5 M C+C R$ & $0.79 \mathrm{a}$ & $0.07 \mathrm{C}$ & & \\
\hline $3 \mathrm{MC}+1 / 5 \mathrm{CF}$ & $0.64 \mathrm{a}$ & $0.20 a b c$ & & \\
\hline $3 M C+C R$ & $0.51 \mathrm{a}$ & $0.23 \mathrm{ab}$ & & \\
\hline
\end{tabular}

$\mathrm{Pi}=$ initial population of the following cultivation and $\mathrm{Pf}=$ final population of $P$. penetrans in each cultivation period per $g$ soil extracted from $20 \mathrm{~g}$ soil (Baermann funnel method).

Cabbage plants were cultivated twice a year in spring and autumn.

$\checkmark$ alues represent the means of 3 replicates.

$\mathrm{Pi} / \mathrm{Pf}$ were analyzed after $\mathrm{B}$ ox-Cox transformation to reduce nonnormality.

M eans followed by the same letter in each colomn were not significantly different according to Tukey's HSD test at the $5 \%$ level.

Chemical fertilizer (CF), manure compost (MC), and crop residue $(C R)$, either separately or in combination, were treated before transplanting the cabbages. amount of compost applied. Pf/Pi of free-living nematodes ranged from 0.37 to 6.32 , with no statistical trend among treatments (A NOVA, P >0.05 df: 4, M S: 0.387, F-value: 2.027).

W hen we performed A NOVA on the Pi and Pf of $P$. penetrans and free-living nematodes and analyzed the effects of cultivated seasons, there were significant differences between spring and autumn cultivations $(P<0.001$ in the $P i$ of $P$. penetrans, $P f$ of $P$. penetrans in 2008-2009, and Pf of free-living nematodes; $P<0.05$ in the $P \mathrm{i}$ of free-living nematodes in 2003-2005), except for the $P f$ of $P$. penetrans in 2003-2005 (A N OVA, P > 0.05, df: 1, M S: 0.041, F-value: 0.093 ) and $P i$ of free-living nematodes in 2008-2009 (A N OVA, P > 0.05, df: 1, M S: 0.020, F-value: 0.001 , Table 8 ). The Pi and P $f$ of $P$. penetrans and $P f$ of free-living nematodes were higher during spring cultivation than during autumn cultivation (Table 8). The mean Pi/Pf of spring cultivation was $0.357(n=15)$ and that of autumn cultivation was $0.729(n=13)$, with statistical difference (A NOVA, P $<0.05$, df: 1, M S: 0.967, F-value: 11.367).

Table 7. The initial population (Pi), the final population (Pf), and the multiplication rate (Pf/Pi) of free-living nematodes in plots treated with organic materials for spring $(S)$ and autumn $(A)$ cabbage cultivation in each year

\begin{tabular}{|c|c|c|c|c|c|c|c|c|c|}
\hline & \multicolumn{3}{|c|}{$2003 S$} & \multicolumn{3}{|c|}{$2003 \mathrm{~A}$} & \multicolumn{3}{|c|}{$2004 S$} \\
\hline & $\mathrm{Pi}^{1}$ & $\mathrm{Pf}^{1}$ & $\mathrm{Pf} / \mathrm{Pi}$ & $\mathrm{Pi}$ & $\mathrm{Pf}$ & $\mathrm{Pf} / \mathrm{Pi}$ & $\mathrm{Pi}$ & Pf & $\mathrm{Pf} / \mathrm{Pi}$ \\
\hline CF & $4.74 \mathrm{a}$ & $10.88 \mathrm{a}$ & $2.37 \mathrm{a}$ & $5.40 \mathrm{a}$ & $2.76 \mathrm{a}$ & $0.59 a$ & $2.55 \mathrm{a}$ & $8.12 \mathrm{a}$ & $3.77 \mathrm{a}$ \\
\hline$M C+1 / 5 C F$ & & $37.45 \mathrm{ab}$ & & $52.33 b$ & $35.76 \mathrm{ab}$ & $0.67 \mathrm{a}$ & $25.17 \mathrm{~b}$ & $135.00 \mathrm{~b}$ & $5.40 \mathrm{a}$ \\
\hline$C F+3 / 5 M C+C R$ & $45.33 \mathrm{~b}$ & 148.37 c & $3.75 \mathrm{a}$ & $53.58 \mathrm{~b}$ & $46.69 a b$ & $0.95 \mathrm{a}$ & $33.70 \mathrm{bc}$ & $132.67 \mathrm{~b}$ & $3.95 \mathrm{a}$ \\
\hline $3 \mathrm{M} \mathrm{C}+1 / 5 \mathrm{CF}$ & & $54.37 \mathrm{ab}$ & & 69.23 bc & 75.48 b & $1.13 \mathrm{a}$ & $39.93 c$ & $253.02 \mathrm{c}$ & $6.32 \mathrm{a}$ \\
\hline \multirow[t]{3}{*}{$3 M C+C R$} & $64.54 \mathrm{~b}$ & 80.97 b & $1.29 \mathrm{a}$ & $100.72 \mathrm{C}$ & $75.29 \mathrm{~b}$ & $0.76 \mathrm{a}$ & $65.18 d$ & $164.03 b c$ & $2.54 \mathrm{a}$ \\
\hline & \multicolumn{3}{|c|}{$2004 \mathrm{~A}$} & \multicolumn{3}{|c|}{$2005 S$} & & & \\
\hline & $\mathrm{Pi}$ & $\mathrm{Pf}$ & $\mathrm{Pf} / \mathrm{Pi}$ & $\mathrm{Pi}$ & $\mathrm{Pf}$ & $\mathrm{Pf} / \mathrm{Pi}$ & & & \\
\hline CF & $5.52 \mathrm{a}$ & $3.41 \mathrm{a}$ & $0.43 a$ & $1.97 \mathrm{a}$ & $9.98 \mathrm{a}$ & $5.09 \mathrm{C}$ & & & \\
\hline$M C+1 / 5 C F$ & $51.67 \mathrm{bc}$ & $46.97 \mathrm{abc}$ & $0.53 \mathrm{a}$ & $29.60 \mathrm{~b}$ & $47.22 \mathrm{ab}$ & $1.40 \mathrm{a}$ & & & \\
\hline$C F+3 / 5 M C+C R$ & $49.49 \mathrm{~b}$ & $30.30 a b c$ & $0.37 \mathrm{a}$ & $40.21 \mathrm{~b}$ & $72.31 \mathrm{abc}$ & $2.90 \mathrm{abc}$ & & & \\
\hline $3 \mathrm{MC}+1 / 5 \mathrm{CF}$ & $79.33 \mathrm{c}$ & 71.48 bc & $0.51 \mathrm{a}$ & $41.43 b$ & $140.53 \mathrm{C}$ & $3.55 \mathrm{bc}$ & & & \\
\hline \multirow[t]{3}{*}{$3 M C+C R$} & $71.67 \mathrm{bc}$ & $86.52 \mathrm{c}$ & $0.70 \mathrm{a}$ & $60.86 c$ & 114.86 bc & $1.80 \mathrm{ab}$ & & & \\
\hline & \multicolumn{3}{|c|}{$2008 \mathrm{~A}$} & \multicolumn{3}{|c|}{$2009 S$} & \multicolumn{3}{|c|}{$2009 \mathrm{~A}$} \\
\hline & $\mathrm{Pi}$ & $\mathrm{Pf}$ & $\mathrm{Pf} / \mathrm{Pi}$ & $\mathrm{Pi}$ & $\mathrm{Pf}$ & $\mathrm{Pf} / \mathrm{Pi}$ & $\mathrm{Pi}$ & $\mathrm{Pf}$ & $\mathrm{Pf} / \mathrm{Pi}$ \\
\hline $\mathrm{CF}$ & $6.03 a$ & $10.14 \mathrm{a}$ & $1.67 \mathrm{ab}$ & $7.37 a$ & $16.11 \mathrm{a}$ & $2.43 \mathrm{ab}$ & $14.45 \mathrm{a}$ & $10.10 \mathrm{a}$ & $0.50 \mathrm{a}$ \\
\hline $\mathrm{MC}+1 / 5 \mathrm{CF}$ & $31.34 \mathrm{ab}$ & $36.30 a b$ & $1.53 \mathrm{ab}$ & $37.00 a b$ & $56.79 a b$ & $1.69 a b$ & $40.46 \mathrm{ab}$ & $39.50 \mathrm{~b}$ & $0.54 \mathrm{a}$ \\
\hline$C F+3 / 5 M C+C R$ & $36.59 \mathrm{~b}$ & $44.11 \mathrm{~b}$ & $1.00 \mathrm{a}$ & $25.93 a b$ & $101.44 a b$ & $3.20 \mathrm{~b}$ & $45.50 \mathrm{~b}$ & $40.50 \mathrm{~b}$ & $0.49 \mathrm{a}$ \\
\hline $3 \mathrm{M} \mathrm{C}+1 / 5 \mathrm{CF}$ & $49.80 \mathrm{~b}$ & $99.91 \mathrm{C}$ & $2.06 \mathrm{ab}$ & 70.83 bc & 108.83 b & $1.33 \mathrm{a}$ & $49.96 \mathrm{~b}$ & $80.39 \mathrm{c}$ & $1.52 \mathrm{a}$ \\
\hline $3 M C+C R$ & $37.85 b$ & $87.85 \mathrm{C}$ & $2.47 \mathrm{~b}$ & $85.74 \mathrm{C}$ & $137.19 \mathrm{~b}$ & $1.90 \mathrm{ab}$ & $63.06 \mathrm{~b}$ & $114.92 \mathrm{~d}$ & $1.71 \mathrm{a}$ \\
\hline
\end{tabular}

${ }^{1} \mathrm{Pi}=$ initial population and $\mathrm{Pf}=$ final population of free-living nematodes in each cultivation period per $\mathrm{g}$ soil extracted from $20 \mathrm{~g}$ soil (Baermann funnel method).

Cabbage plants were cultivated twice a year in spring and autumn.

$\checkmark$ alues represent the means of 3 replicates.

$\mathrm{Pi}, \mathrm{Pf}$ and $\mathrm{Pf} / \mathrm{Pi}$ were analyzed after B ox-Cox transformation to reduce non-normality.

$\mathrm{M}$ eans of Pi, Pf and Pf/Pi in each colomn followed by the same letter were not significantly different according to Tukey's HSD test at the $5 \%$ level.

Chemical fertilizer $(C F)$, manure compost $(M C)$, and crop residue $(C R)$, either separately or in combination, were applied before transplanting the cabbages. 
Table 8. The initial population $(\mathrm{Pi})$ and the final population (Pf) of Pratylenchus penetrans and free-living nematodes during spring and autumn cabbage cultivation in 2003-2005 and in 2008-2009

\begin{tabular}{|c|c|c|c|c|c|c|c|c|c|}
\hline \multirow{3}{*}{$\begin{array}{l}\text { Cultivated } \\
\text { season }\end{array}$} & \multirow{3}{*}{ Cultivar } & \multicolumn{4}{|c|}{ P. penetrans } & \multicolumn{4}{|c|}{ Free-living nematodes } \\
\hline & & \multicolumn{2}{|c|}{$2003-2005$} & \multicolumn{2}{|c|}{$2008-2009$} & \multicolumn{2}{|c|}{$2003-2005$} & \multicolumn{2}{|c|}{$2008-2009$} \\
\hline & & $\mathrm{Pi}^{1}$ & $\mathrm{Pf}^{1}$ & $\mathrm{Pi}$ & $\mathrm{Pf}$ & $\mathrm{Pi}$ & $\mathrm{Pf}$ & $\mathrm{Pi}$ & $\mathrm{Pf}$ \\
\hline Spring & K inkei 201 & 3.40 & 7.59 & 3.93 & 8.72 & 40.21 & 93.98 & 45.38 & 84.07 \\
\hline A utumn & $\begin{array}{l}\text { Shutoku or } \\
\text { Shutoku SP }\end{array}$ & 1.11 & 5.19 & 1.71 & 4.03 & 53.89 & 47.47 & 37.50 & 56.37 \\
\hline & $\mathrm{ANOVA}^{2}$ & & $\mathrm{~ns}$ & & & & *** & ns & \\
\hline
\end{tabular}

${ }^{1} \mathrm{Pi}=$ initial population and $\mathrm{Pf}=$ final population of $\mathrm{P}$. penetrans in each cultivation period per $\mathrm{g}$ soil extracted from $20 \mathrm{~g}$ soil (Baermann funnel method). Cabbage plants were cultivated twice a year in spring and autumn.

$\mathrm{Pi}$ and $\mathrm{Pf}$ were analyzed after $\mathrm{B}$ ox-Cox transformation to reduce non-normality. ${ }^{2}$ T hree-factor analysis of variance (A N OVA) results of Table $5 . * *: \mathrm{P}<0.01$

Table 9. Number of Pratylenchus penetrans and free-living nematodes per $\mathrm{g}$ soil amended with compost in the pot experiment

\begin{tabular}{ccccc}
\hline & $\begin{array}{c}\text { M anure } \\
\text { compost } \\
\%(w / v)\end{array}$ & $7 / 20 / 2010$ & $9 / 3 / 2010$ & $10 / 4 / 2010$ \\
(0 day) & (45 days) & (76 days) \\
\hline \multirow{3}{*}{ P. penetrans } & control & & $7.25 \pm 0.87 \mathrm{a}$ & $4.25 \pm 0.41 \mathrm{a}$ \\
& $1 \%$ & $10.87 \pm 1.75$ & $6.10 \pm 0.71 \mathrm{a}$ & $3.27 \pm 0.38 \mathrm{ab}$ \\
& $3 \%$ & & $5.53 \pm 0.71 \mathrm{a}$ & $2.46 \pm 0.31 \mathrm{~b}$ \\
\hline \multirow{2}{*}{ Free-living } & control & & $27.08 \pm 1.69 \mathrm{a}$ & $10.54 \pm 1.37 \mathrm{a}$ \\
nematodes & $1 \%$ & $18.35 \pm 0.96$ & $23.88 \pm 1.95 \mathrm{a}$ & $15.43 \pm 1.54 \mathrm{~b}$ \\
& $3 \%$ & & $27.33 \pm 2.55 \mathrm{a}$ & $36.00 \pm 4.18 \mathrm{c}$ \\
\hline
\end{tabular}

M eans \pm SE $(n=10)$

Nematode populations were analyzed after B ox-Cox transformation to reduce non-normal ity.

For the treatments, means followed by the same letter in rows were not significantly different according to Tukey's HSD test at the $5 \%$ level.

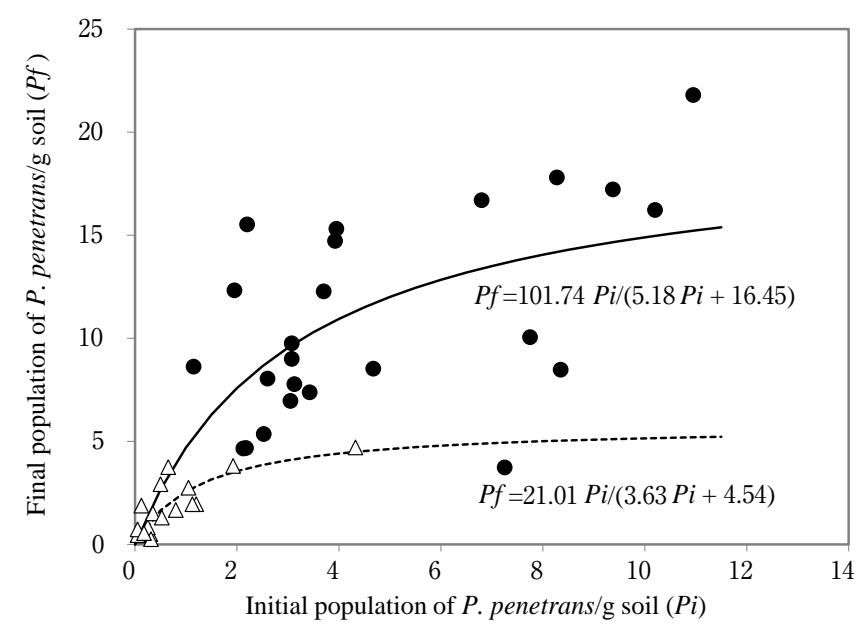

Fig. 1. Regression curves for the Pratylenchus penetrans population in a cabbage field treated with $C F(\mathbf{O})$ and $3 M C+C R(\triangle)$; reference data.
In this study, the cabbage cultivation periods ranged from 66 to 91 days in spring and 89 to 106 days in autumn. The effective accumulative soil temperatures (degree-days) for P. penetrans calculated according to M izukubo and A dachi (1997) for spring and autumn cultivations in each year ranged from 791 to 1713 and 1114 to 1261 degree-days, respectively. The fitted curves for spring and autumn were $y=36.689 x-1611.3$ with $r^{2}$ $=0.9967(\mathrm{P}<0.05$, y: effective accumulative soil temperatures, $x$ : cabbage growing-days) and $y=7.4222 x$ +467.2 with $r^{2}=0.8797$ ( $P>0.05$, y: effective accumulative soil temperatures, $\mathrm{x}$ : cabbage growingdays), respectively. There was no significant relationship between the effective accumulative soil temperatures and $P f$ of $P$. penetrans in either spring or autumn cultivations.

\section{Pot experiments:}

In the pot experiment, P. penetrans numbers significantly decreased at 45 days after the incorporation 
Table 10. Results of the model curve regression variables for the $P$. penetrans population based on Seinhorst model, $\mathrm{Pf}=\mathrm{aEPi} /((\mathrm{a}-1) \mathrm{Pi}+\mathrm{E})$ in the cabbage field affected by soil treatments

\begin{tabular}{lcccccc}
\hline Treatment & D ata sets & $\mathrm{a}^{\mathrm{l}}$ & $\mathrm{E}$ & $\mathrm{r}^{2}$ & $\begin{array}{c}\text { P value } \\
(\mathrm{a})\end{array}$ & $\begin{array}{c}\text { P value } \\
(\mathrm{E})\end{array}$ \\
\hline $\mathrm{CF}$ & 24 & 6.18 & 16.45 & 0.257 & 0.0172 & $<0.001$ \\
$\mathrm{MC}+1 / 5 \mathrm{CF}$ & 21 & 1971 & 7.32 & 0.000 & $>0.05$ & $<0.001$ \\
$\mathrm{CF}+3 / 5 \mathrm{M} \mathrm{C}+\mathrm{CR}$ & 24 & 29.18 & 8.34 & 0.051 & $>0.05$ & $<0.001$ \\
$3 \mathrm{M} \mathrm{C}+1 / 5 \mathrm{CF}$ & 18 & 31.87 & 2.99 & 0.049 & $>0.05$ & $<0.001$ \\
$3 \mathrm{M}$ C + CR & 21 & 4.63 & 4.54 & 0.657 & 0.0020 & $<0.001$ \\
\hline
\end{tabular}

${ }^{1} \mathrm{a}=$ rate of multiplication at $\mathrm{Pi} \rightarrow 0 ; \mathrm{E}=$ equilibrium density.

Chemical fertilizer (CF), manure compost (MC), and crop residue $(C R)$, either separately or in combination, were applied before transplanting the cabbages.

of compost (Table 9). A clear trend was found in this experiment, whereby the incorporation of more compost in pots resulted in lower numbers of $P$. penetrans. The population of free-living nematodes in $90 \mathrm{t} /$ ha compost plots increased significantly at 76 days after the incorporation of compost.

\section{A pplication of the model formula:}

$W$ hen we assessed the significance of the factors (year, cultivation season, and block) of Pi and Pf of P. penetrans, some factors showed statistically significant differences and needed to be applied separately to the formula. However, because of the presence of 2 independent variables ( $a$ and $E$ ) in the formula, we believed that the divided sample number according to the significance of the factors would be too small to analyze. Therefore, we performed curve fitting with the entire data set of each treatment (Table 10) and used this as reference data.

Using DataFit software, we obtained 2 curves each for $C F$ and $3 M C+C R$, with 6.18 and 4.63 representing a (the "rate of multiplication") and 16.45 and 4.54 representing $E$ (the "equilibrium density"), respectively (Fig. 1, Table 10). We were unable to obtain curves for $M C+1 / 5 C F, C F+3 / 5 M C+C R$, and $3 M C+1 / 5 C F$, since the $P$ values for a were higher than 0.05 . However, all the $P$ values for $E$ of these treatments were less than 0.001 , with $8.34,7.32$, and 2.99 representing $E$, respectively. Hence, twice-yearly applications of $97 \mathrm{t} /$ ha sawdust cattle manure compost with $33 \mathrm{t} / \mathrm{ha}$ of cabbage crop residue lowered the equilibrium density of $P$. penetrans from 16.45 to 4.54 individuals/g soil.

\section{DISCUSSION}

While cabbage is a good host for $P$. penetrans, it is also, to a certain extent, tolerant to this pest. A ccording to
Olthof and Potter (1973), an initial P. penetrans density of 6,000 individuals $/ \mathrm{kg}$ soil is required to cause a decline in the top weights of cabbage plants. In the current study, in 2005S, for example, there was no significant difference in the above-ground weights of cabbage plants between the $\mathrm{CF}$ treatment and $\mathrm{CF}+3 / 5 \mathrm{MC}+\mathrm{CR}$ treatment, which had $\mathrm{Pi}$ values of 9.32 and 2.63 individuals/g soil, respectively. Hence, in this study, host plant growth did not appear to be markedly restricted by the increases in $P$. penetrans population size. The soil pH in CF plots was very low during the latter half of the experiment (from 2006 to 2009; Table 4), probably because of $\left(\mathrm{N} \mathrm{H}_{4}\right)_{2} \mathrm{SO}_{4}$ mixed in CF. However, the presence of severe soil-borne diseases (such as clubroot disease, the severity of which increases under low soil pH conditions; M urakami et al., 2002) was not observed throughout the experiment.

The nematode population sizes in the experimental plots were not assessed just before cabbage was first grown; however, the distributions of $P$. penetrans and free-living nematodes in the plots did not vary greatly because the host plants of $P$. penetrans had been uniformly cultivated for approximately 15 years in the plots and the experimental plots were arranged in a randomized complete block design (3 blocks). In M ay 2003 , following the planting of the first cabbage crops in the previous autumn, the population sizes of $P$. penetrans in the $3 M C+C R$ plot were smaller than those in the $C F$ plot (Table 5). The P. penetrans population in the $3 \mathrm{MC}+$ $C R$ plots seemed to have been suppressed by the treatment. The population size of $P$. penetrans in the $3 M C+C R$ plots was kept consistently small and those in the CF plot kept consistently large until the end of the 15th planting in 2009, although the $\mathrm{Pf} / \mathrm{Pi}$ and $\mathrm{Pi} / \mathrm{Pf}$ values after the 2nd planting did not differ much among treatments. It is not clear whether there was a suppressive effect of the treatment on $P$. penetrans multiplication 
during cultivation after the 2nd planting, as it is well known that $\mathrm{Pi}$ values affect $\mathrm{Pf} / \mathrm{Pi}$ values (M CSorley and Gallaher, 1995) and a direct comparison of $\mathrm{Pf} / \mathrm{Pi}$ values with different $\mathrm{Pi}$ values was not possible.

In the case of $P$. penetrans, $P f / P i$ of spring and autumn cultivations did not differ much or show any tendency among treatments (Table 5). The range of effective accumulative temperatures for $P$. penetrans growth for autumn cultivations in experimental years completely overlapped with that of spring cultivations, while the grow th of host plants (cabbage) for each treatment was greater in spring than in autumn and the $\mathrm{Pi}$ of $P$. penetrans was relatively higher in spring cultivation than in autumn cultivation (Table 8). On the basis of these results, the host plant growth for all the treatments did not seem to limit the multiplication of $P$. penetrans in both cultivation periods.

Seinhorst (1967) demonstrated that the maximum rate of multiplication and equilibrium density of nematode populations depend on external conditions. In other words, unfavorable conditions may reduce both the maximum rate of multiplication and equilibrium density of a nematode species compared to other populations of the same species under optimal external conditions. To clarify the effect of compost application on the P. penetrans population, we applied the model formula of Seinhorst (1966) and compared the relationship between the initial and final densities of migratory nematodes; $3 M C+C R$ and $C F$ fitted the model formula. The other three treatments did not get significant a (rate of multiplication), since the $\mathrm{Pf}$ values corresponding to lower $\mathrm{Pi}$ varied greatly. However, the $\mathrm{Pf}$ values of higher $\mathrm{Pi}$ each converged to significant $\mathrm{E}$ (equilibrium density). By comparing the equilibrium density values of $P$. penetrans derived from the model formula for treatments, we observed that the application of higher amounts of sawdust cattle manure compost reduced the equilibrium density to a greater degree (Table 10). Because food availability for plant-feeding nematodes did not seem to limit nematode multiplication, the unfavorable external conditions of continuous organic material application seem to cause the low multiplication rate and low equilibrium density observed in the $3 \mathrm{MC}+$ $C R$ and $3 M C+1 / 5 C F$ treatments in the field experiment. The results of our pot experiment support this observation.

Regarding the observed population fluctuation of $P$. penetrans in the $3 M C+C R$ and $C F+3 / 5 M C+C R$ or $3 M C+1 / 5 C F$ treatments and the amount of organic materials that were applied in each treatment, we could not confirm that $C R$ application affected the population density of $P$. penetrans to a greater extent than the same amount of $M C$. Hence, the influence of $C R$ on $P$. penetrans survival might be similar to that of $M C$, although cabbage is known to contain isothiocyanateliberating glucosinolates (K irkegaard and Sarwar, 1998) and is a potential biofumigation candidate.

The population drops of $P$. penetrans during fallow periods may be caused by the host plants' absence, antagonistic biological activities (Stirling, 2014; Stirling, et al., 2005), and environmental disturbance from the tillage after harvest ( $R$ ahman, et al., 2007). The population of $P$. penetrans was reduced to a greater extent after spring cultivation than autumn cultivation, although the cultivation interval was shorter after spring cultivations. This may be because of higher chemical and biological activities under high temperature during the cultivation interval after spring cultivation. The absolute $P i$ and $P f$ values of $P$. penetrans and free-living nematodes for each treatment did not differ substantially throughout the experimental period; i.e., after the 2nd cultivation until the 15th cultivation. This means that cattle manure compost application twice a year to the soil affected the population levels of $P$. penetrans and freeliving nematodes before and after crop cultivation; however, the rate of change did not increase progressively.

Possible factors that cause the suppression of population grow th include accumulated nitrogenous compounds derived from organic materials ( $\mathrm{Oka}$ and Yermiyahu, 2002; Renčo et al., 2010) and/or biological mechanisms that cause the number of antagonistic and non-antagonistic microorganisms to increase in the soil (J affee et al., 1998; Stirling et al., 2005). The results of our pot experiment show that $1 \%(\mathrm{w} / \mathrm{v})$ manure compost application reduced the population of $P$. penetrans effectively. Oka and Yermiyahu (2002) showed that the application of 200 to $1000 \mathrm{~m}^{3} /$ ha cattle manure compost is effective in lowering the Meloidogyne javanica galling index in tomato plants, even though the compostamended soil in pots was washed with excess water. The EC values of the field soil in our study were much lower than those reported by $0 \mathrm{ka}$ and Yermiyahu (2002), possibly because of the differences in compost composition and preparation. Considering that the concentration of the compost used in this study was approximately $300 \mathrm{~m}^{3} / \mathrm{ha}$ (100 t/ha), the amount of nitrogenous compounds in the soil might be similar to those in the washed soil in the study of $0 \mathrm{ka}$ and Yermiyahu (2002), and this might be a reason for the 
suppression of the $P$. penetrans population.

The results of this study show that the population of free-living nematodes increased through the incorporation of manure compost. Several studies have reported the biological suppression of plant-parasitic nematodes by compost treatments accompanied with population increases of free-living nematodes. For instance, Jaffee et al. (1998) demonstrated that, although the difference was not great, more species of nematodetrapping fungi were found in compost-treated organic plots than in conventional inorganic plots. In a sugarcane field experiment conducted by Stirling et al. (2005), the populations of Pratylenchus zeae and Tylenchorhynchus annulatus in soil amended with sugarcane trash were reduced by $85 \%$ and $71 \%$, respectively. They found that amendments increased microbial activity and the number of free-living nematodes, but had no effect on known predators such as dorylaimid and mononchid nematodes or nematode-trapping fungi (although an unidentified predatory fungus was found in only amended soil). Stirling (2014) has explained the role of free-living nematodes: "bacteria and fungi that decompose organic matter are consumed by bacterivorous and fungivorous nematodes, and since they then become a food source for generalist predators, continuous organic inputs are the key to maintaining a diverse range of natural enemies". The abiotic and biotic effects of organic material application were hypothesized to cause the decline in $\mathrm{P}$. penetrans population under conditions of continuous cabbage cultivation in the field.

On the basis of our results, we concluded that the application of 32 to $53 \mathrm{tFW} / \mathrm{ha}$ of sawdust cattle manure compost was insufficient to suppress the population of $P$. penetrans. Rather, 97 to $130 \mathrm{tFW} /$ ha of sawdust cattle manure compost appeared to be sufficient for the stable suppression of $P$. penetrans population levels. A pplication of organic material at 97 to $130 \mathrm{tFW} /$ ha per cultivation period greatly exceeded the normal application level in Japan. Near the area of Tsukuba, which is where the experimental field was located, the $\mathrm{CF}+3 / 5 \mathrm{MC}+\mathrm{CR}$ treatment is the standard amount of organic material applied for cabbage cultivation, and heavy organic material application would not be considered as a mainstream procedure for $P$. penetrans suppression. Further studies for providing quantitative information about the limits for the practical application of composts to crops will be needed. The suppression mechanisms of $P$. penetrans in the current system are expected to clarify the effects of organic materials on plant parasitic nematode population dynamics.

\section{ACK NOW LEDGEMENTS}

We thank Dr. T. M izukubo, from the NARO A gricultural Research Center, for the identification of $P$. penetrans and for his helpful comments and advice on the manuscript. We also thank Dr. T. M itsunaga, from the NARO A gricultural Research Center, for his helpful advice on statistical analysis. We also thank M r. N. Sakamoto, from the National Institute of Vegetable and Tea Science, for his technical assistance.

\section{LITERATURE CITED}

A bawi, G. S. and Widmer, T. L. (2000) I mpact of soil health management practices on soilborne pathogens, nematodes and root diseases of vegetable crops. A pplied Soil Ecology 15, 37-47.

Chikaoka, I., Ohbayashi, N . and Shiina, K. (1971) Studies on the integrated control of northern root lesion nematode (Pratylenchus penetrans) infected on Japanese radish (M iuradaikon). Bulletin of the K anagawa Prefectural A gricultural Corporated Experimental Research Organization 2, 1-50. (in Japanese with an English summary)

Hagiya, S., Shinohara, S. and Shirasaki, T. (1982) Population fluctuations of P ratylenchus penetrans in carrot fields and effects of marigold for the control of the nematode. Bulletin of Chiba A gricultural Experiment Station 23, 21-29. (in Japanese with an English summary)

Jaffee, B. A ., Ferris, H. and Scow, K. M. (1998) Nematode-trapping fungi in organic and conventional cropping systems. Phytopathology 88(4), 344-350.

K ajino, Y. (1986) The actual occurrence condition of nematodes in edible burdock fields in Tokachi area. Hokunou 53, 14-25. (in Japanese, provisional translation by author)

K irkegaard, J. A . and Sarwar, M. (1998) Biofumigation potential of brassicas. Plant and Soil, 201, 71-89.

M cSorley, R. and Gallaher, R. N. (1995) Effect of yard waste compost on plant-parasitic nematode densities in vegetable crops. Supplement of the Journal of Nematology 27(4S), 545-549.

M iller, P. M . (1978) Reproduction, penetration, and pathogenicity of Pratylenchus penetrans on tobacco, vegetables, and cover crops. Phytopathology 68, 1502-1504.

M izukubo, T. (2004) Identification of Pratylenchus spp. and Hirschmanniella spp. in Japan. Plant Protection Extra edition 8, 17-22. (in Japanese) 
M izukubo, T. and A dachi, H. (1997) Effect of temperature on Pratylenchus penetrans development. J ournal of Nematology 29(3), 306-314.

M urakami, H., Tsushima, S., K uroyanagi, Y. and Shishido, Y. (2002) Reduction of resting spore density of Plasmodiphora brassicae and clubroot disease severity by liming. Soil Science and Plant Nutrition 48(5), 685-691.

Nahar, M. S., Grewal, P. S., M iller, S. A., Stinner, D., Stinner, B. R., K leinhenz, M. D., Wszelaki, A. and Doohan, D. (2006) Differential effects of raw and composted manure on nematode community, and its indicative value for soil microbial, physical and chemical properties. A pplied Soil Ecology 34, 140151.

Nakasono, K. (1992) Effect of organic materials on soil nematodes. In: Progress in Nematology. (Nakasono, $K$. ed.), The Japanese Nematological Society, Tsukuba, 258-261. (in J apanese)

Ohbayashi, N. (1989) Studies on the methods for controlling the root-lesion nematode, Pratylenchus penetrans Cobb infecting on J apanese radish. Bulletin of $\mathrm{K}$ anagawa Horticultural Experiment Station 39, 1-90.

Oka, Y. (2010) M echanisms of nematode suppression by organic soil amendments - A review. A pplied Soil Ecology 44, 101-115.

Oka, Y. and Yermiyahu, U. (2002) Suppressive effects of composts against root-knot nematode M eloidogyne javanica on tomato. Nematology 4 (8), 891-898.

Olthof, T. H. A . and Potter, J. W. (1973) The relationship between population densities of Pratylenchus penetrans and crop losses in summer-maturing vegetables in O ntario. Phytopathology 63, 577-582.

Rahman, L., Chan, K. Y. and Heenan, D. P. (2007) Impact of tillage, stubble management and crop rotation on nematode populations in a long-term field experiment. Soil \& Tillage Research 95, 110-119.

Renčo, M., Sasanelli, N., D’Addabbo, T. and Papajová, I. (2010) Soil nematode community changes associated with compost amendments. Nematology 12(5), 681692.

Seinhorst, J. W. (1966) The relationships between population increase and population density in plant parasitic nematodes I. I ntroduction and migratory nematodes. Nematologica 12, 157-169.

Seinhorst, J. W. (1967) The relationships between population increase and population density in plant parasitic nematodes. III. Definition of the terms host, host status and resistance. IV. The influence of external conditions on the regulation of population density. Nematologica 12, 157-169.

Stirling, G. R. (2014) Biological control of plant-parasitic nematodes, 2nd edition, Soil ecosystem management in sustainable agriculture. CA B Internaional, Wallingford, U K, 510pp.

Stirling, G. R., Wilson, E. J., Stirling, A. M ., Pankhurst, C. E., M oody, P. W., Bell, M. J. and Halpin, N. (2005) A mendments of sugarcane trash induce suppressiveness to plant-parasitic nematodes in a sugarcane soil. A ustralasian Plant Pathology 34, 203211.

Uragami, A ., A izawa, S., K unihisa, M. Murakami, K. Tokuda, S. and Higashio, H. (2009) Soil incorporation of waste asparagus rootstock from rootstock planting forcing culture reduces soil densities of Pratylenchus penetrans (Cobb) and damage to subsequent lettuce yield. Nematological Research 39(1), 23-30. (in Japanese with an English summary).

Received: February 26, 2013 